\title{
Henrik Halkier
}

\section{Samfundsforskning og tekst \\ - det skotske tilfælde som metodisk problem}

\begin{abstract}
The present paper explores some possible links between linguistics and social science, departing from an example of textual analysis originating in research in progress. Particular attention is paid to the characteristics of historical textual analysis and to the relationship between social phenomena and the concepts employed by social scientists. It is argued that the presence of common theoretical problems and shared methodologies provides an interesting starting point for future interdisciplinary research and for up-to-date teaching of post-graduate students.
\end{abstract}

\section{Introduktion*}

Undervisningen i samfundsfag ved de erhvervssproglige fakulteter har gennem det seneste årti fået større vægt. Først og fremmest for at øge de studerendes baggrundsviden og ruste dem til at indgå i interkulturel kommunikation, men også fordi de metodiske aspekter af samfundsfagsundervisningen ville kunne styrke de studerendes evner til selvstændigt at indsamle, vurdere og præsentere information. Dette undervisningsbehov har medført, at der gennem de seneste år blevet ansat en eller flere samfundsvidenskabelige forskningsmedarbejdere på de fleste erhvervssproglige fakulteter. Forskning i samfundsforhold er med andre ord blevet introduceret i erhvervssprogligt regi ud fra hovedsageligt undervisningsmæssige overvejelser, og netop derfor vil det være relevant at se nærmere på forskningsområdets relation til den $\emptyset$ vrige forskning på institutionerne.

Artiklens formål er således at påpege eksistensen af faglige anknytningspunkter mellem samfundsforskning og sprogforskning, både i form af en metodisk beslagtethed og en række falles grundproblemer. Efter indledningsvis at have diskuteret særtræk ved samfundet som forskningsobjekt, tager fremstillingen udgangspunkt i et konkret eksempel på samfundsforskning i et erhvervssprogligt miljø, nemlig en tekstanalyse hen-

\footnotetext{
* Tak til deltagerne i Lingvistisk Kollokvium ved Handelshøjskolen i Århus 3.10.89 for konstruktive kommentarer. En særlig tak til den skotske økonom John Scouller, der en mørk december-eftermiddag på Strathclyde University i Glasgow stillede en tilrejsende samfundsforsker det afgørende spørgsmål: "What is your methodology?"
} 
tet fra mit projekt "Curing the Industrial Disease - Policies for Industrial Development in Scotland". På grundlag heraf drøftes især to metodiske problemstillinger, nemlig

- tekst-anvendelse indenfor samfundsforskningen, og

- forholdet mellem begreber og virkelighed.

\section{Samfundet som forskningsobjekt}

Umiddelbart kunne det måske nok virke besynderligt at give sig til at lede efter anknytningspunkter mellem to forskningsområder, hvis erkendelsesinteresser er så forskellige: mens lingvistikken undersøger sproget, er samfundsforskningens erkendelsesinteresse af ikke-sproglig art, nemlig tilvejebringelse af viden om strukturer og forandringer $i$ samfundene.

Allerede fokuseringen på "strukturer og forandringer", der pointerer samfundsforskningens analytiske dimension, gør imidlertid opkomsten af faglige grænseflader mere plausibel. I modsætning til andre typer fremstillinger af samfundsforhold, som f.eks. journalistik eller krønikeskrivning, tilsigter samfundsforskning ikke blot at opregne og beskrive umiddelbart iagttagelige fænomener, men også at fremdrage relationer i tid og/eller rum mellem fænomener der ellers for en umiddelbar betragtning ikke står i forbindelse med hinanden. Undersøger man f.eks. hvilke faktorer der har været anvendt til at forklare, hvorfor Mrs Thatcher har været i stand til at fastholde premierminister-posten i mere end 10 år, støder man ikke alene på umiddelbart iagttagelige træk ved det politiske liv i Storbritanien såsom enkeltsmandskredsene og to-parti systemet, men også fænomener som f.eks. industrialismens krise i Storbritanien eller sammenbruddet af efterkrigstidens politiske konsensus (jvf. Jessop et al. 1988).

Hermed er et grundlæggende metodisk problem blevet bragt på bane, for hvorledes sikrer man sig at sådanne 'dybereliggende forklaringer' bliver andet og mere end smarte postulater eller politisk ønsketænkning? Hvor går grænsen mellem på den ene side den for forskningen $n \phi d v e n-$ dige forenkling, og på den anden side en uholdbar 'begrebs-imperialis$m e^{\prime}$ uden forbindelse til virkeligheden?

Dette problem forstærkes af den særlige karakter, samfundsforskningens objekt har. Uanset om enkelt-individerne eller de sociale relationer mellem dem betragtes som konstituerende for et samfund (se hertil Calinicos 1987), så indgår mennesker som potentielt aktivt handlende aktører, udstyret med vilje og muligheden for refleksion, i ethvert samfund, og hvad enten denne mulighed for aktiv handlen udnyttes i større eller min- 
dre omfang, så medfører mulighedens blotte tilstedeværelse et element af uforudsigelighed i samfundsudviklingen.

Selvom man naturligvis kun kan beskæftige sig videnskabeligt med samfundsudviklinger, der allerede har fundet sted, så har konstateringen af menneskers potentielle uberegnelighed væsentlig betydning for samfundsforskningens karakter. Det bliver ganske enkelt vanskeligt at hævde, at samfundsudviklingen generelt er styret af een usynlig hånd: det være sig fremskridtet som hos oplysningstidens historikere, produktivkræfternes udvikling som hos marxisterne, eller markedet som hos mange $\varnothing$ konomer. Der vil i samfundene være et potentiale for uberegnelig adfærd, overfor hvilken samfundsforskningen uvægerligt vil komme til kort, hvis den tager udgangspunkt i en form for universel skematik. Alternativet er naturligvis mere kompliceret: nemlig at tage udgangspunkt i en sammenligning af fænomener indenfor og imellem forskellige samfund, for at se i hvilket omfang det er muligt at udsondre generelle tendenser; noget der stiller krav om konstant opmærksomhed med hensyn til de enkelte begrebers anvendelighed i forskellige samfund på forskellige tidspunkter.

Den potentielt uregerlige karakter af samfundsforskningens objekt skærper med andre ord spændingen mellem begrebslig forenkling og 'begrebsimperialisme' som allerede kravet om en analytisk tilgangsvinkel skabte. Spørgsmålet om, hvorledes samfundet kan sættes på begreb, er med andre ord ikke uproblematisk, og interessen for hvilke begreber der anvendes og deres relation til virkeligheden udgør en første faglig grænseflade mellem samfundsforskningen og lingvistikken.

\section{Samfundsforskning i praksis: et eksempel}

For at illustrere de metodiske - både håndværksmæssige og teoretiske — problemer, der knytter sig til at fremdrage "strukturer og forandringer i samfundene", tager diskussionen udgangspunkt i et konkret eksempel. Først introduceres projektet og dets baggrund og perspektiver kort, og derefter ses nærmere på den konkrete forskningsproces i form af et eksempel på historisk tekstanalyse.

\section{1 "Curing the Industrial Disease \\ - Policies for Industrial Development in Scotland"}

For 100 år siden var Storbritanien verdens førende industrimagt og stod for mere end en fjerdedel af verdens samlede industrieksport; i dag går de-industrialiseringens spøgelse gennem den tidligere 'workshop of 
the world', mens Storbritanien er netto-importør af industrivarer. Det kan måske ikke undre - andre end nationalistiske briter — at en lille $\varnothing$ med begrænsede menneskelige og naturlige ressourcer ikke for tid og evighed kan bevare en kvantitativ dominans på industri-området, men hvorfor mistede britisk industri sin kvalitative fører-position med hensyn til produktivitet og teknisk udvikling? Og hvad kunne man gøre for at genfinde dynamikken fra den industrielle revolution og forhindre, at Storbritanien bliver EF's industrielle og økonomiske agter-lanterne?

Forskningsdebatten om årsagerne til 'the decline of British industry' er særdeles omfattende ${ }^{1}$, og har også været udgangspunktet for nærværende projekt, hvis formål er

at analysere skotsk industripolitiks udvikling med særlig henblik på at klarlægge de sociale, politiske og økonomiske forhold der har haft indflydelse herpå.

Skotland er valgt som case-studie pga. områdets i britisk sammenhæng enestående kombination af repræsentativ industristruktur og en lang tradition for industripolitiske tiltag, og som det fremgår af problemformuleringen søger projektet på at klarlægge to ting. For det første hvordan skotsk industripolitik har udviklet sig, dvs. hvilke strategiske mål er blevet forfulgt hvornår af offentlige myndigheder og private organisationer; noget der iøvrigt i sig selv er en større opgave på grund af mangfoldigheden af modstridende industripolitiske målsætninger, lige fra bevarelse af arbejdspladser for enhver pris, over systematisk fremme af bestemte nye eller gamle industri-sektorer, til fremme af (skotsk) nationalistiske eller parti-politiske formål. For det andet søges klarlagt hvorfor skotsk industripolitik har udviklet sig som tilfældet er, dvs. hvilke faktorer, der har haft bestemmende indflydelse på opkomsten af officielle industripolitiske tiltag — nye udviklinger i skotsk økonomi, pression fra interesseorganisationer eller partipolitiske hensyn.

Set med danske $\varnothing$ jne er det skotske tilfælde endvidere særligt interessant, fordi Danmark efter gennemførelsen af EF's indre marked i 1992 på mange måder vil befinde sig i en 'skotsk' situation — umiddelbart nord for en langt større og stærkere økonomi uden selvstændige makro- $\varnothing \mathrm{ko-}$ nomiske styringsmidler - og en opfindsom industripolitik vil derfor hurtigt kunne blive af afgørende betydning, også for dansk økonomi.

1 Klassiske bidrag til debatten er Pollard 1983, Gamble 1985, Wiener 1981, Hall 1987 og Anderson 1987. For kritisk oversigt over debatten, se Warwick 1985, Coates \& Hillard (eds.) 1987 samt Halkier 1989. 


\section{2 "Scotland - An Economic Profile" - en historisk tekstanalyse}

Når man skal tilvejebringe viden om udviklingen af skotsk industripolitik spiller arbejdet med tekster en central rolle, sådan som det generelt er tilfældet i samfundsforskning. Enten tekster i form af eksisterende videnskabelig litteratur om emnet, eller i form af kilde-tekster der direkte eller indirekte har indgået $\mathrm{i}$ den historiske proces man ønsker at studere.

Da der kun er skrevet ganske få videnskabelige arbejder om skotsk industripolitik $^{2}$, må projektet i hovedsagen baseres på originalt kildemateriale. En af de publikationer, der er blevet hjembragt fra Skotland er en farvestrålende tryksag på 80 A4-sider: "Scotland - An Economic Profile" (Scottish Office 1988). Udgiveren er Scottish Office (Ministeriet for skotske anliggender), og en analyse af forordet herfra (gengivet som illustration til denne artikel) vil kunne illustrere nogle grundlæggende forhold og problemer i forbindelse med tekstanalyse i en samfundsvidenskabelig kontekst.

\subsubsection{Kommunikationssituation og budskab}

De første spørgsmål, der skal besvares, må være: hvilken kommunikationssituation indgår teksten $\mathrm{i}$, og hvad er dens budskab? Tekstens afsender fremgår umiddelbart i kraft af underskriften og billedet: Industriministeriet under Scottish Office, personificeret af den skotske industriminister Ian Lang. Tekstens centrale budskab er heller ikke vanskeligt at få $\emptyset j$ på: fra første til sidste linie gælder det om at overbevise læseren om, at skotsk økonomi er blevet moderniseret.

Den forventede modtager af budskabet er straks vanskeligere at fastlægge. De eneste eksplicitte modtager-angivelser i teksten er meget brede — 'too many people' (lin. 12) og 'the world' (lin. 17) — og begge placeret i umiddelbar tilknytning til det forældede (engelske) 'late 19th Century music hall' image (lin. 14f), som teksten skal være modvægt til (lin. 5f, 16f). Ved at tage udgangspunkt i bogens emne og overveje, hvem der kunne tænkes at være interesseret i en populær, men detaljeret fremstilling af skotsk økonomi, vil man kunne nå frem til en mere præcis målgruppe, der kunne tænkes at ligge under for engelske fordomme om Skotland: bogens kombination af glitrende lay-out og sagligt økonomisk indhold synes at være skræddersyet til udenlandske investorer, der overvejer at

2 De vægtigste bidrag er Moore \& Booth 1989, Keating \& Midwinter 1983, og Hood \& Young (eds.) 1984. 
investere i Skotland, men som kunne tænkes at nære fejlagtige forestillinger om landets $\varnothing$ konomiske tilstand.

Mediet for budskabet er offentligt — bogen kan købes hos boghandleren - og man må derfor antage at hensynet til afsenderens offentlige position vil begrænse mængden af faktuelle fejl, omend et offentligt medie naturligvis ikke i sig selv giver nogen 'sandheds-garanti'. Tekstens genre er et 'forord', dvs. en teksttype man normalt ville forvente ville være præget af personlige eller holdningsmæssige elementer, snarere end faktuelle, og der vil derfor være god grund til at kigge nærmere efter tekstens tendens, dvs. dens normative elementer.

Et iøjnefaldende normativt træk ved teksten er, at moderniseringen af skotsk økonomi karakteriseres med ord som 'growth areas of the future' (lin. 4f), 'progress' (lin. 6), 'competitive' (lin. 20, 22), 'advanced' (lin. 22), 'enterprise and initiative' (lin. 23f), så skotsk økonomi alt i alt 'can confidently face the future' (lin. 26). Moderniseringen vurderes med andre ord som et positivt fænomen.

Ved at se nærmere på spørgsmålet om tekstens afsender kan man imidlertid lokalisere endnu et normativt element. Som tidligere nævnt er der formelt set ingen tvivl om afsender-forholdet: teksten er jo underskrevet af den skotske industriminister. Usikkerheden melder sig først når man nærlæser teksten, hvor der er mange eksplicitte referencer til afsenderen, men til gengæld en vis uklarhed om hvem 'we' og 'us' refererer til. I nogle tilfælde kan der kun være tale om skotterne som nation (lin. 4, 8, 13, 24), mens der i andre tilfælde enten muligvis (lin. 3) eller sandsynligvis (lin. 16) refereres til Scottish Office og dermed den nuværende konservative regering. Gennem brug af det samme pronomen med inklusiv eller tvetydig reference, underst $\varnothing t t e t$ af et diskret placeret Skotlands-kort bag ministeren på billedet, forsøges skabt en identifikation mellem tre ting: den konservative regering, skotterne som nation og moderniseringen af skotsk $\varnothing$ konomi - og da de to sidstnævnte faktorer er positivt ladede bliver den konservative regering det også. Hermed bliver det nødvendigt at udvide i det mindste selve forordets målgruppe, da man nok må formode at dette normative budskab i vidt omfang er beregnet til indenlandsk konsum som led i kampen om vælgernes gunst, f.eks. i forbindelse med den officielle præsentation af udgivelsen i de skotske medier. 


\subsubsection{Tekst og industripolitik}

Først efter denne indledende analyse af tekstens budskab og den kommunikationssituation, den indgår i, kan man forsøge at besvare det egentlige spørgsmål, nemlig hvilke informationer om skotsk industripolitik er det muligt at udsondre af teksten?

For det første har teksten vist sig at berette om bestemte sagsforhold, nemlig eksplicit 1) at der er foregået en modernisering af den skotske $\emptyset$ konomi, og implicit 2) at den konservative regering har spillet en rolle heri. Disse påstande kan naturligvis ikke uden videre tages for pålydende: tekstens trovardighed som beretning må vurderes i forhold til de enkelte udsagn, ikke mindst fordi den konservative industriminister har gode markedsføringsmæssige motiver til at give et forvrænget billede af virkeligheden, f.eks. ved at fremstille den økonomiske udvikling i et urimeligt rosenrødt skær eller ved uretmæssigt at påberåbe sig fadderskabet til en af andre årsager stedfunden $\emptyset$ konomisk udvikling.

Vurderingen af troværdigheden kan kun ske gennem sammenligning med andre tekster, og man vil her formentlig komme til at stå i den akavede, men langtfra usædvanlige, situation, at der i en række forskellige tekster med hver deres motiver til at give tendentiøse fremstillinger af virkeligheden fremkommer modstridende udsagn om f.eks. fadderskabet til det skotske $\varnothing$ konomiske mirakel. Hvis man skal kunne drage slutninger på grundlag af teksters beretninger om sagsforhold, er det et ufravigeligt krav, at der kan demonstreres overensstemmelse mellem flere indbyrdes uafhongige kilder, fordi troværdigheden af et bestemt udsagn styrkes af at have fundet nedslag i flere af hinanden uafhængige sammenhænge. Det er f.eks. oplagt, at troværdigheden af de konservatives krav om fadderskab ikke styrkes af, at forordet er 'typisk' eller 'repræsentativt' i den forstand at Ian Lang gentager de samme påstande ved enhver given lejlighed, fordi alle ytringerne kan føres tilbage til eet bestemt sted. Det er endvidere vigtigt at understrege, at kravet om uafhængighed til tider indebærer en meget bred fortolkning: på grund af det britiske to-parti system vil f.eks. både Labour og de konservative have - modsatrettede — årsager til at overdrive betydningen af Thatcher-regeringens tiltræden for skotsk industripolitik, og man vil her qua den politiske polarisering kunne finde en form for afhængighed mellem tekster, der for en umiddelbar betragtning dårligt kunne blive mere uafhængige. 
FIGUR 2

Udover at analysere tekstens mere eller mindre troværdige beretning om skotsk industripolitik, er det også muligt udfra teksten at drage slutninger om dennes ophavssituation (jvf. illustrationen). Det forhold, at det tilsyneladende er magtpåliggende at skabe en identifikation mellem de skotske vælgere og den konservative regering kan tolkes som udtryk for skarpet parti-konkurrence; de konservative har hårdt brug for at manifestere sig efter 1987-valget, hvor partiet trods Thatchers sejr kun erobrede 10 mandater i Skotland mod Labours 50. Tekstens fremkomst kan endvidere ses som udtryk for interne modsatninger blandt de offentlige institutioner, der forvalter skotsk industripolitik. Sammenligner man med andre officielle udgivelser om skotsk $\emptyset$ konomi er det påfaldende, at "Scotland - An Economic Profile" genre- og lay-out-mæssigt ligger i solid forlængelse af den professionelle og glitrende marketing-strategi, som Scottish Development Agency har anvendt (f.eks. SDA 1981, 1985, 1986a, 1986b), og samtidigt markerer et tydeligt brud med Scottish Office's hidtidige udgivelser på området, der har været præget af en spartansk og lidt gammeldags præsentationsform ${ }^{3}$. Da medierne har tilskrevet det delvist uafhængige Scottish Development Agency en stor del af æren for moderniseringen af skotsk økonomi, har Scottish Office — og ikke mindst de konservative ministre - god grund til at forsøge at lukrere på den politiske good-will i forbindelse med tiltrækningen af udenlandske investeringer til Skotland, f.eks. ved at stå for publikationer som "Scotland An Economic Profile".

3 De skibsværfter og skæggede skotter med kilt, der pryder forsiden af Scottish Information Office 1987 er iøvrigt et glimrende eksempel på det 'late 19th Century music hall image' Ian Lang polemiserer så kraftigt mod — og som Scottish Office åbenbart har gjort sit til at udbrede. 
Når man på denne måde drager slutninger fra teksten til dens ophavssituation, dvs. tolker fremkomsten af teksten og/eller dens indhold som udtryk for bestemte omstændigheder omkring tekstens tilblivelse, kan dette ske på to måder. Enten er det muligt direkte at drage logiske slutninger udfra selve teksten, som f.eks. når gentagne forbud mod en bestemt handlemåde peger på, at denne handlemåde må have været udbredt i et bestemt samfund. Eller også drages der slutninger på grundlag af viden om den samfundsmæssige og kulturelle sammenhæng teksten udspringer fra; f.eks. forudsatte den ovenstående tolkning kendskab til 2-parti systemet og den særlige britiske form for 'adversarial politics', samt til den oprindelige opgavefordeling mellem Scottish Office og Scottish Development Agency.

Antagelser om hvilke handlinger der i en given situation er socialt rationelle spiller med andre ord en central rolle, og hermed introduceres et væsentligt usikkerhedsmoment, fordi rationalitet hænger sammen med adfærdsformer og sociale mikro-strukturer der i høj grad er bundet i tid og rum samt indbyrdes overlappende, og fordi man må leve med risikoen for at en bestemt handling eller tekst kunne udgøre et brud med den herskende rationalitet. Når man søger udfra teksten at drage slutninger om baggrunden for dens tilblivelse er det derfor særligt vigtigt at overveje alternative forklaringer på de tekst-træk, der lægges til grund for tolkningen, og at kunne demonstrere overensstemmelse mellem flere uafhængige kilder.

Vi antager for eksperimentets skyld, at ovenstående analyse stemmer overens med resultatet af analysen af andre, ikke indbyrdes afhængige, kilder. Hvad kunne man i så fald slutte om skotsk industripolitik udfra "Scotland - An Economic Profile"?

Altså hvis ... Den konservative regering har spillet en væsentlig rolle i moderniseringen af skotsk økonomi, dvs. bidraget til afviklingen af sværindustri og andre forældede produktionsformer og i stedet fremmet udviklingen af fleksibel højteknologisk produktion indenfor f.eks. elektronikog medico-industri. Denne industripolitik har været i modstrid med traditionel Labour-politik, og dens gennemførelse har bl.a. krævet at Scottish Office har overtaget opgaver fra det af Labour i 1975 oprettede Scottish Development Agency. Alt i alt kan man således konkludere, at 80'ernes konservative parti har ført an i omstillingen af den skotske økonomi fra den kriseplagede fordistiske masseproduktion til moderne post- fordisme 
med højteknologi og fleksibel specialisering 4 . De konservative har med andre ord været post-fordismens politiske spydspids i Skotland.

Lad os, efter denne konklusion er nået, træde et skridt tilbage og overveje hvilke metodiske problemer og perspektiver, det netop gennemgåede eksempel på historisk tekstanalyse implicerer. Et iøjnefaldende problemfelt er forholdet mellem begreber og virkelighed i samfundsforskningen, herunder hvilken rolle mere abstrakte begreber som f.eks. 'postfordisme' kan spille, og dette vil blive diskuteret i afsnit 5. Først skal opmærksomheden imidlertid rettes mod andre spørgsmål, som melder sig i kølvandet på eksemplet, nemlig hvilken status tekstanalysen har indenfor samfundsforskningen, og i forlængelse heraf dens anknytningspunkter til andre aktiviteter i erhvervssprogligt regi.

\section{Samfundsforskning og tekstanalyse}

Det er naturligvis vigtigt at overveje, hvorvidt det netop diskuterede eksempel er repræsentativt. Har praktisk samfundsforskning overhovedet brug for tekstanalyse? Denne tilgangsvinkel kunne jo i det ovenstående eksempel være nødvendiggjort af, at der med overlæg er valgt en usædvanlig 'dårlig' tekst med stærk politisk tendens og dubiøs oprindelseshistorie. Ville man ikke kunne klare sig enten helt uden tekster, eller nøjes med få 'gode' og 'objektive' tekster? Og hvordan adskiller historisk tekstanalyse sig fra den måde, tekster anvendes på i forbindelse med sprogforskning?

\subsection{Teksters placering i forskningsprocessen}

For en umiddelbar betragtning forekommer det langt fra indlysende, at tekster skulle være samfundsforskningens vigtigste råmateriale. Hvorfor indskyde et ekstra led med alle de ovenfor opregnede muligheder for forvrængning, når forskeren i stedet selv kunne gå ud i samfundet for direkte at gøre iagttagelser?

En nødvendig forudsætning for analyse af samfundsmæssige strukturer og forandringer er at disse er blevet fastholdt på en eller anden måde. Helt simple forhold såsom antallet af ministre i Scottish Office er det naturligvis muligt at skaffe sig viden om uden at ty til tekster, f.eks. ved at overvære et minister-møde og foretage en simpel optælling. Men så snart undersøgelsesarbejdet enten vedrører samfundsudviklinger, der allerede har fundet sted, eller fænomener af kompleks karakter der ud-

4 Begrebsparret fordisme/post-fordisme vil blive diskuteret i afsnit 5.3. 
spiller sig mange steder på een gang, kan forskeren ikke være personligt tilstede og gøre sine iagttagelser. Man er derfor henvist til at betjene sig af informationer, der er blevet 'lagret' på en eller anden måde, og selv det 20. århundredes kakofoniske udbud af elektroniske lyde og billeder har ikke kunne fortrænge skreven/trykt tekst som et centralt lagringsmedie.

Hertil kommer, at mange samfundsfænomener direkte manifesterer sig i form tekster, fordi forskellige grupper i samfundet har interesse i at kunne fastholde en bestemt indbyrdes relation, f.eks. i form af indgåelse af aftaler og kontrakter eller udarbejdelse af politiske programmer. Tekster er således ofte den nærmeste vej til informationer om undersøgelsesobjektet.

\subsection{Nødvendigheden af tekstanalyse}

Ikke alene anvendelse, men også analyse af tekster indgår imidlertid som en integreret del af videnskabelige unders $\emptyset$ gelser af samfundsforhold. Dette kan sandsynliggøres med udgangspunkt i hosstående grafiske fremstilling af nogle centrale undersøgelsesfelter i mit forskningsprojekt.

\section{FIGUR 3}

Sålænge man udelukkende forsøger at kortlægge udviklingen indenfor del-aspekter af de enkelte institutioners adfærd på det industripolitiske område (dvs. billedligt talt at man udforsker indholdet af een af de små kasser), forekommer behovet for videregående tekstanalyse ikke umiddelbart at være så påtrængende. Det skulle principielt være muligt at belyse både udviklinger i overordnede strategiske overvejelser og den industripolitiske praksis - organisationernes politiske pression og myndighedernes konkrete tiltag — ved hjælp af autentisk dokumentarisk materiale, som direkte har indgået $\mathrm{i}$ den historiske proces. Gennem indsamling af 
f.eks. årsberetninger, policy-statements, aftaler og kontrakter ville der kunne skabes klarhed over "hvem der sagde/gjorde hvad hvornår".

Selv dette kortlægningsarbejde vil imidlertid hurtigt kunne komme til at indeholde tekstanalytiske elementer. Enten på grund af praktiske omstændigheder: når de originale dokumenter ikke kan tilvejebringes, må man nøjes med materiale hvis ophavssituation er placeret så tæt på det undersøgte fænomen som muligt. Eller af principielle årsager, fordi klassifikationen af konkrete politiske krav eller enkeltstående administrative afgørelser ofte vil indebære en tolkning af det originale dokument. Allerede i forbindelse med relativt simple spørgsmål som kortlægning af delaspekter af enkelte institutioners industripolitiske adfærd er forskerens opgave således sjældent begrænset til indsamling af 'gode' og 'objektive' tekster, der uden videre leverer de ønskede informationer.

Søger man at belyse mere komplicerede forhold såsom relationer mellem forskellige instanser (dvs. billedligt talt pilene på ovenstående diagram) bliver tekstanalyse et uomgængeligt arbejdsredskab. Vil man f.eks. undersøge, hvem eller hvad der i 1975 fik den daværende Labour-regering til at oprette Scottish Development Agency, finder man frem til at

- forskellige partier og interesseorganisationers krav om industripolitisk sær-

behandling for Skotland foreligger i skriftlig form

- samtidige avisudtalelser fra involverede Labour-politikere gengiver de officielle bevaggrunde, som offentligheden præsenteredes for, og

- i heldigste fald kan der skaffes adgang til interne referater fra kabinetsmøderne.

Altsammen mere eller mindre troværdige gengivelser af "hvem der sagde hvad hvornår" i den politiske proces. Men een afgørende brik mangler: båndoptagelser af hvad der foregik inde i hovedet på beslutningstagerne i 1975, der direkte, neutralt, autentisk og troværdigt ville have registreret, hvilke politiske hensyn der reelt lå til grund for beslutningen. Sådanne båndoptagelser kan ikke tilvejebringes, og spørgsmålet om hvem eller hvad der fik Labour til at oprette Scottish Development Agency må med andre ord besvares på grundlag af materialer, hvis troværdighed man på forhånd har god grund til at være skeptisk overfor.

Vi står her overfor et generelt problem, fordi hovedparten af de strukturer og forandringer, samfundsforskningen beskæftiger sig med, involverer sociale relationer, dvs. tilbagevendende adfærdsmønstre i samkvemmet mellem samfundets individer. Sådanne mønstre bliver ikke automatisk registreret af en 'neutral og pålidelig' instans, fordi sociale relationer 
som f.eks. magt bl.a. virker et absolut utilgængeligt sted, nemlig inde i hovedet på det enkelte individ, og hvad der foregår her findes der i sagens natur kun tendentiøse og/eller indirekte vidnesbyrd om.

Nødvendigheden af historisk tekstanalyse er således snævert forbundet med de spørgsmål, samfundsforskningen søger at besvare, og tekstanalytiske overvejelser spiller derfor en central rolle i samfundsforskningen, lige fra planlægning af materialeindsamlingen til bearbejdelsen af de indsamlede tekster.

\subsection{Historisk tekstanalyse - et komparativt perspektiv}

Hvilke forskelle og ligheder i forhold til den måde, tekster anvendes på i forbindelse med sprogforskning, har ovenstående eksempel på historisk tekstanalyse peget på?

For det første kan der konstateres iøjnefaldende ligheder på det rent 'håndværksmæssige' område, dvs. hvorledes man læser flertydige tekster og forstår budskabet både på og mellem linierne. Her kræves ikke alene en omfattende baggrundsviden med hensyn til terminologien indenfor det pågældende sagsområde, men også til de stilistiske konventioner og virkemidler indenfor forskellige tekstgenrer. Betydningen af, i hvilken sammenhæng en bestemt ytring fremsættes, giver kontaktflader til pragmatikken, og fremgangsmåden, når tekster tolkes som et tegn på bestemte forhold i ophavssituationen, bringer mindelser om semiotiske analyser, ligesom afstanden mellem (lingvistiske) diskursanalyser og undersøgelser af ideologi- eller mentalitetshistorisk tilsnit forekommer beskeden. Der viser sig med andre ord at være en hel række anknytningspunkter mellem samfundsforskning og lingvistik med hensyn til de anvendte tilgangsvinkler i forskningsprocessen.

Den afgørende forskel består i, at tekstanalyse i samfundsvidenskabelige sammenhænge systematisk er orienteret mod konteksten. Ikke alene fordi den endelige erkendelsesinteresse er ekstra-sproglig, men også fordi sammenligning med andre tekster og inddragelse af baggrundsviden om teksternes sociale og kulturelle sammenhæng spiller en fremtrædende rolle. Den enkelte tekst bliver med andre ord i høj grad opfattet som et medie, der indeholder mere eller mindre skjulte 'budskaber', og den historiske tekstanalyses opgave er følgeligt at etablere retningslinier for hvorledes denne 'dekodning' kan og skal foregå, så der på grundlag af kildeteksterne kan drages slutninger om virkeligheden.

Eksisterende lærebøger i historisk metode (f.eks. Dahl 1975, Clausen 1974) lægger hovedvægten på, hvordan forskellige typer tekster kan ud- 
nyttes, udfra hvilke kriterier nogle kilde-tekster kan foretrækkes fremfor andre, og ved hjælp af hvilke begrundelsesforhold det er muligt at danne historiske teorier om samfundets udvikling på basis af teksterne. Der fokuseres kort sagt på den fase af arbejdet, hvor teksterne er blevet analyseret, og forskeren på grundlag af en lang række analyseresultater skal fors $\emptyset$ ge at etablere nogle gyldige udsagn om for- eller samtiden. Udfra forskningens erkendelsesinteresse kan det næppe undre, at traditionen metodisk set yder det største selvstændige bidrag på netop dette område, men uheldigvis har denne prioritering i praksis betydet, at selve analysen af den enkelte kildetekst gives væsentligt mindre vægt; man synes at forudsætte, at historikere og samfundsforskere i forvejen kan læse tekster. Det er imidlertid ikke nфdvendigvis tilfældet, og da analysen af de enkelte tekster er de byggestene, der kan føre frem til etableringen af mere omfattende udsagn om virkeligheden, er denne 'sorte metodiske plet' højst uheldig. Mere omfattende og systematiske overvejelser på dette område ville næppe være skadelige for tekstanalyse i samfundsfagligt regi, og $\mathrm{i}$ betragtning af de ovenfor skitserede anknytningspunkter ville inddragelse af metoder udviklet indenfor lingvistikken kunne yde et særdeles betydningsfuldt bidrag på dette område.

Det kan således konstateres, at der faktisk eksisterer adskillige metodiske berøringsflader mellem samfundsforskning og andre aktiviteter i erhvervssprogligt regi. Der er heller ikke tvivl om, at udnyttelse af muligheden for samarbejde på tværs af traditionelle faggrænser ville kunne vise sig at være af stor betydning for begge parter: mens samfundsforskningen kunne bibringes en mere systematisk tilgang til arbejdet med de enkelte tekster, så ville man fra denne side forhåbentligt kunne yde et konstruktivt bidrag med hensyn til forholdet mellem tekst og kontekst.

\section{Begreber og virkelighed}

Ovenstående diskussion har koncentreret sig om forskellige etaper på vejen fra tekst til komplekse videnskabelige hypoteser. Det følgende afsnit vil gå et skridt videre og se på, udfra hvilke overvejelser samfundsforskningen sætter samfundet på begreb. En videnskab, der har til hensigt at tilvejebringe viden om strukturer og forandringer i samfundene er naturligvis nødt til at kunne gøre rede for, hvilken status dens begreber og konklusioner kan tillægges i forhold til virkeligheden, og som antydet i forbindelse med ovenstående eksempel er forholdet mellem begreb og virkelighed, herunder hvilken rolle mere abstrakte begreber kunne tænkes at spille, langtfra uproblematisk. 


\section{1 'Reale begreber' vs. teoretiske modeller}

Traditionelt har valget indenfor samfundsforskningen stået mellem enten at opfatte de anvendte begreber som reale, dvs. at begreberne er et entydigt udtryk for reelt eksisterende samfundsfænomener, eller at betragte begreber som tilnærmede teoretiske modeller af virkeligheden.

Den grundlæggende tankegang indenfor real-begreb traditionen er, at begreber dannes ved at generalisere udfra konkrete iagttagelige fænomener, og at abstrakte begreber dannes ved at generalisere udfra mindre abstrakte begreber. Starter man f.eks. med Scottish Engineering Employers Association er der ingen tvivl om, at dette begreb henviser entydigt til et fænomen, der kan iagttages i 105 West George St. i Glasgow i form af kontorpersonale og mødeaktiviteter, og på grundlag heraf kan man så ved generalisering nå frem til begreber som 'arbejdsgiverforening' og 'interesseorganisation'. Når der generaliseres udfra konkret iagttagelige fænomener, hvor der er en entydig korrespondance mellem begreb og fænomen (fordi begrebet reelt er et proprium), vil de mere generelle begreber også referere til fænomener i virkeligheden på en entydig måde (jvf. nedenstående figur).

Denne opfattelse af forholdet mellem begreber og virkelighed har været herskende indenfor en lang række meget forskellig traditioner indenfor samfundsforskningen, og man kunne fristes til at tro, at opfattelsens brede appel bl.a. ligger i, at samfundsforskningen som konsekvens heraf pr. definition producerer 'sande' resultater, dvs. gyldige udsagn om den måde, virkeligheden er indrettet på. Denne styrke peger samtidigt på et afgørende problem, fordi opfattelsen af begreber som 'reale' indebærer, at virkeligheden kun kan opfattes på een måde og beskrives ved hjælp af eet sæt begreber. Den faktiske udvikling af samfundsvidenskaberne har imidlertid været alt andet end monolitisk - verden er blevet beskrevet på højst forskellige måder - og noget kunne derfor tyde på, at 'reale begreber' ikke er nogen hensigtsmæssig beskrivelse af forholdet mellem begreber og virkelighed.

FIGUR 4 
Et ofte fremført alternativ hertil indenfor samfundsvidenskaberne er at opfatte begreber som teoretiske modeller af virkeligheden, hvor man gennem den videnskabelige proces gradvist søger at præcisere begreberne og konklusionerne, så de bliver så god en tilnærmelse til virkeligheden som muligt. Den grundlæggende tankegang er her, at forskeren ikke kan konfrontere sine videnskabelige hypoteser direkte med samfundet, men kun med et til lejligheden etableret empirisk materiale. Etableringen af empirien indebærer både en udvoelgelse af bestemte udsnit af virkeligheden, samt en organisering af denne udfra nogle bestemte principper, og empirien er derfor ikke a-teoretisk, men afspejler en bestemt forskningstraditions problemstillinger og grundantagelser. Forskningens resultater afhænger med andre ord af de spørgsmål der stilles, og begrebsapparatet udgør kun en sproglig tilnærmelse til, men er $i k k e$ identisk med virkeligheden.

Denne opfattelse af forholdet mellem begreber og virkelighed, der står i stor gæld til Karl Poppers 'kritiske rationalisme', genfindes ligeledes indenfor de mest forskellige forskningstraditioner, og også her er opfattelsens intuitive appel nærliggende: der levnes masser af plads til opkomsten af konkurrerende videnskabelige traditioner, og kravet om at producere sand viden er opgivet til fordel for den mindre ambitiøse ide om 'tilnærmede modeller'. Forholdet mellem model-begreber og virkeligheden udg $\varnothing \mathrm{r}$ imidlertid stadig et problem. Model-traditionen gør pr. definition begreb og virkelighed til kvalitativt forskellige størrelser, og når empirien er konstrueret ved hjælp af teoretiske begreber bliver brugen af ordet 'tilnærmet' en logisk set uopfyldelig hensigtserklæring. Den eneste måde model-tilnærmelsen kan ske på er nemlig gennem introduktion af nye begreber, hvorfor den jomfruelige (begrebsløse) virkelighed til evig tid vil undslippe begrebsliggørelse, fordi hvordan skal man på forhånd vide i hvilken retning virkeligheden befinder sig, når den ikke er sat på begreb?

Model-begreber som alternativ til de 'reale begreber's monolitiske sandheds-monopol truer således med at gøre samfundsforskning til en række mere eller mindre tilfældige forsøg på systematisk italesættelse af virkeligheden, der umuligg ør en kritisk dialog imellem forskellige videnskabelige traditioner, fordi man på tværs af forskellige skoler aldrig kan være sikker på at tale om det samme. Der synes at være god grund til at se nærmere på andre mulige opfattelser af forholdet mellem begreb og virkelighed. 


\subsection{Mulige løsninger: 'Diskursanalyse' eller 'realisme'}

Indenfor samfundsvidenskaberne har 'diskursanalyse' gennem det sidste årti spillet en fremtrædende rolle, ikke mindst blandt angelsaksiske sociologer (f.eks. Laclau \& Mouffe 1985, 1987), der i høj grad er blevet inspireret af nyere fransk filosofi og sprogforskning (cf. Anderson 1983).

Udgangspunktet for den diskurs-analytiske tradition er opgivelsen af ideen om, at samfundet eksisterer som en selvstændig ekstra-sproglig realitet. Tegn og symboler opfattes i stedet som en integreret del af adfærdsmønstret indenfor de sociale systemers 'diskursive totalitet', hvad enten det er den katolske kirke i Italien, de politiske partier i Skotland eller den danske roliganisme der tænkes på. Man har med andre ord etableret et studieobjekt, der — i det mindste delvist — består af tegn og sproglige repræsentationer, og dermed bliver systematisk viden om samfundsfænomener mulig, da der ikke længere er et kvalitativt spring mellem studieobjekt og videnskab.

Også denne traditions umiddelbare appel, ikke mindst til 'the chattering classes', er nærliggende: ord er en social realitet, der må tages alvorligt på linie med materielle forhold. Set udfra spørgsmålet om forholdet mellem begreb og virkelighed er traditionens bidrag imidlertid mere problematisk, netop fordi den 'diskursive totalitet' ikke er en essentialistisk enhed, men en i princippet vilkårlig kombination af forskellige lingvistiske og ekstra-lingvistiske elementer indenfor rammerne af en social praksis (jvf. Jensen 1988). Dette forudsætter nemlig, at dele af samfundet - de ekstra-lingvistiske elementer af de 'diskursive totaliteter' - foreligger i en form, der ikke umiddelbart er begrebsliggjort, og samfundsforskeren må således fortsat selv sætte dele af samfundet på begreb, enten fordi de fortolkes på modstridende måder af de involverede parter eller måske slet ikke italesættes af aktørerne selv.

Den diskursanalytiske tradition, der ved første øjekast så ud til at kunne omgå dilemmaet mellem reale begreber og model-begreber ved simpelthen at omdefinere samfundsforskningens objekt, viser sig bag de omfattende ord-guirlander blot at reproducere problemet indenfor de dele af samfundet, der ikke i sig selv er umiddelbart begrebsliggjort. 
Hvis samfundsforskningen, uagtet alle teoretiske fortrædeligheder, alligevel synes at have afdækket genkendelige mønstre i virkeligheden, hvor fordelingen af økonomiske og andre ressourcer øver en 'stum' tvang overfor de enkelte individer (jvf. Halkier 1987), så må ord og begreber indenfor samfundsforskningen i et ikke uvæsentligt omfang referere til en de facto eksisterende social realitet. I forlængelse af denne tankegang kunne en frugtbar løsning være at tilføje en præmis til den kritiske rationalisme ${ }^{5}$, nemlig at der eksisterer en vis, men ikke nфdvendigvis fuldstandig korrespondance mellem begreber og virkelighed. Det er muligt, at denne sprogfilosofiske eller erkendelsesteoretiske antagelse allerede ligger implicit i forestillingen om model-begreber, og 'blot' er gledet i baggrunden $\mathrm{i}$ forbindelse med polemikken mod real-begrebs traditionen, men fordelene ved eksplicit formulering heraf synes at være talrige.

Aksiomets indførelse betyder nemlig først og fremmest, at empiri ikke længere er en teoretisk konstruktion, men 'blot' en tendentiøs og partiel repræsentation af virkeligheden. Der eksisterer med andre ord flere mulige empiri'er, hvorfor flere fortolkninger af det samme fænomen er mulige eller ligefrem sandsynlige. Hermed får begreber i samfundsforskningen status af forpligtende hypoteser om sammenhænge i virkelighedens verden, dvs. begreber og teorier siger noget væsentligt om samfundet, men må konstant genovervejes som følge af den grundlæggende usikkerhed omkring begrebsliggørelsen af samfundet. Muligheden herfor fremmes bl.a. af, at meningsfuld kritisk dialog mellem forskellige videnskabelige traditioner er mulig, fordi disse har en fælles referenceramme i form af virkeligheden. Dette betyder også, at det ikke er afgørende, hvorvidt samfundsfænomener er italesat af de involverede parter eller ej, fordi forskeren under alle omstændigheder vil betragte de involverede parteres egen fremstilling gennem skeptiske briller og i stedet nå frem til sine egne konklusioner ved at konfrontere en række stadigt præcisere begreber og hypoteser med sit empiriske materiale. Man kan med andre ord konkludere, at en videnskab om strukturer og forandringer i samfundene principielt er mulig, og at denne samfundsforskning hverken vil udvikle sig som en-dimensional monolit eller resultere i et relativistisk kaos, men derimod sandsynligvis vil have en flertydig karakter.

\footnotetext{
5 Det skal understreges, at indførelsen af den samme præmis i real-begrebs traditionen principielt ville kunne have fået præcis de samme konsekvenser, men at den kritiske rationalisme på grund af dens eksplicitte skelnen mellem empiri/virkelighed og vægtning af eksistensen af flere videnskabelige traditioner i praksis vil være en mere direkte fremgangsmåde.
} 
Denne måde at opfatte forholdet mellem begreber og virkelighed på indskriver sig i en metodisk tradition, der indenfor samfundsvidenskaberne er blevet lanceret under betegnelsen 'realisme' (Sayer 1984, McLennan 1981, 1982, 1983). Hvis man ellers kan abstrahere fra betegnelsens propagandistiske overtoner, viderebringer selve ordet 'realisme' i virkeligheden ret præcist to centrale pointer, nemlig 1) at samfundsvidenskab kan producere viden om samfundet på en kritisk og rationel måde, men 2) at videnskabens muligheder for at finde forklaringen nødvendigvis begrænses af den grundlæggende usikkerhed i forholdet mellem begreber og virkelighed.

\subsection{Begrebstyper i samfundsforskningen}

Efter at have forvisset sig om at samfundsforskning kan handle om virkeligheden, bliver det næste spørgsmål, hvorvidt man på forhånd kan udpege nogle begreber som mere eller mindre hensigtsmæssige at anvende. Var det f.eks. rimeligt, at konklusionen på ovenstående tekstanalyse satte de skotske konservative i forbindelse med et så besynderligt abstrakt begreb som 'post-fordisme'?

Tages der udgangspunkt i den netop skitserede 'realisme' vil der ikke være noget principielt $\mathrm{i}$ vejen for at anvende endog meget abstrakte begreber i samfundsforskningen. Hvis abstrakte begreber fremkommer gennem en serie generaliseringer vil de nemlig kunne underkastes empirisk kontrol på en måde, der ikke er kvalitativt forskellig fra, hvad mere hverdagsagtige begreber kan blive udsat for.

Vil man f.eks. vurdere, hvorvidt det er rimeligt at opfatte de konservative som post-fordismens spydspids i Skotland, vil dette indebære en kæde af konfrontationer mellem de anvendte begreber og den samfundsmæssige virkelighed. Udgangspunktet må naturligvis være en definition af begrebet 'post-fordisme', der er tilstrækkelig præcis til at være operationel. Indenfor den såkaldte 'regulerings-teori' har økonomer karakteriseret de vestlige industrisamfunds nuværende situation som en overgangsfase, hvor samfundene bevæger sig væk fra den hidtil dominerende fordistiske masseproduktion (Fords samlebånd) i retning af post-fordisme, karakteriseret ved fleksibel specialisering indenfor en højteknologisk produktion (Jessop 1983, cf. Hirsch \& Roth 1986, Allen \& Massey (eds.) 1988). Det er udfra definitionen muligt at vurdere

1) hvorvidt teoridannelsen er internt konsistent. Er 'fleksibel specialisering' en kvalitativt ny udviklingsfase, eller blot den traditionelle masseproduktion med et mere differentieret design — et fænomen man måske kunne kalde Opel'isme? 
2) hvorvidt teoridannelsen generelt stemmer overens med udviklingen i de industrialiserede lande. Er det korrekt at masseproduktionen er ved at forsvinde?

Overlever begrebet post-fordisme skærsildens to første led, står man overfor den sidste og afgørende test, nemlig

3) hvorvidt begrebet kan anvendes konkret til forklaring af det skotske tilfælde.

Befinder skotsk $\emptyset$ konomi sig i en overgangsfase mellem fordisme og post-fordisme, og i bekræftende fald: har den konservative regerings industripolitiske initiativer spillet en afgørende rolle heri?

Abstrakte begreber er altså på ingen måde 'farligere' eller mere 'begrebs-imperialistiske' end andre begrebstyper; tværtimod synes meget generelle og abstrakte begreber at leve livet særlig farligt indenfor en empirisk orienteret samfundsforskning. Anvendeligheden af absolutte universelle sammenhænge og udviklingstendenser synes at være begrænset, når forskningsobjektet indeholder potentielt uforudsigeligt handlende individer og man iøvrigt ikke kan forudsætte en entydig relation mellem begreber og virkelighed. Studieobjektets uregerlige karakter (jvf. afsnit 2) og begrebsliggørelsens fundamentale skrøbelighed (jvf. afsnit 5.2) betyder nemlig tilsammen, at historicering, dvs. omhyggelig overvejelse af de enkelte begrebers relevans i den konkrete situation, er af afgørende betydning.

Det er således et grundvilkår i samfundsforskningen, at begrebsliggørelsen af samfundet er en fortløbende proces, der udspilles i spændingsfeltet mellem nødvendig forenkling og truslen om 'begrebs- imperialisme'. Forholdet mellem begreber og virkelighed synes ikke at kunne 'løses' een gang for alle, men opmærksomhed på problemets eksistens og karakter vil være en nødvendig forudsætning for ethvert systematisk forsøg på at sætte samfund på begreb.

\section{Perspektivering}

Der har gennem artiklen kunnet konstateres en række faglige anknytningspunkter mellem samfundsforskning og lingvistik. Udover en række grundlaggende problemstillinger af erkendelsesteoretisk eller sprogfilosofisk art, er der blevet påvist en direkte metodisk beslagtethed, der udspringer af den centrale rolle tekstanalyse spiller indenfor begge traditioner. Det er endvidere tydeligt, at traditionerne, på grund af forskellige erkendelsesinteresser, systematisk har udviklet forskellige aspekter af analysen af tekster og kontekster.

Denne kombination af ligheder og forskelle peger på, at der kunne være interessante forskningsmassige perspektiver $\mathrm{i}$ at undersøge den grå 
zone mellem samfunds- og sprogforskning på tværfaglige basis, f.eks. i form af konkrete undersøgelser af bestemte tekstgenrer i massemedierne eller i form af mere teoretiske studier af forholdet mellem tekst og kontekst. Sådanne tværfaglige initiativer ville formentlig kunne gennemføres mest fordelagtigt gennem samarbejde mellem specialister uddannet indenfor for de to metodiske traditioner, f.eks. ved at trække på de samfundsforskere der er ansat i lingvistiske miljøer, eller — hvorfor ikke? — ved at ansætte lingvister i samfundsfaglige eller historiske forskningsmiljøer.

Den metodiske beslægtethed er endvidere perspektivrig set fra et undervisningsmaessigt synspunkt. Den virkelige verden er som bekendt fuld af sympatisk udseende Ian Lang'er, der fra hvert deres gadehjørne stormer os i møde med tilbud vi ikke kan afslå, og derfor vil selvstændig indsamling og vurdering af informationer blive af afgørende betydning, når dansk erhvervsliv skal stå sin prøve på det indre europæiske marked. Her vil erhvervssproglige kandidater kunne komme til at yde et vigtigt bidrag, fordi deres faglige forudsætninger som tekstlæsere er velegnet som udgangspunkt for en videregående systematisk beskæftigelse med teksternes mere eller mindre troværdige forhold til virkeligheden. Der vil med andre ord gennem en relativt beskeden indsats - fastholdelse af en metodisk orienteret samfundsfagsundervisning — kunne opnås betragtelige resultater, både for de erhvervssproglige fakulteter og de mennesker vi uddanner.

Noget kunne tyde på, at hvad der startede som fornuftsægteskabelig co-habitation ville kunne udvikle sig til en ganske frugtbar sameksistens. 


\section{Litteratur}

Allen, John \& Doreen Massey (eds.) (1988): The Economy in Question. London: Sage.

Anderson, Perry (1983): In the Tracks of Historical Materialism. London: Verso.

Anderson, Perry (1987): The Figures of Descent, i: New Left Review 161, 1987, 20-77.

Callinicos, Alex (1987): Making History. Cambridge: Polity.

Clausen, H. P. (1974): Hvad er historie? København: Berlingske.

Coates, David \& John Hillard (eds.): The Economic Decline of Modern Britain. The Debate Between Left and Right. Brighton: Wheatsheaf.

Dahl, Ottar (1975): Grunntrekk i historieforskningens metodelare. Oslo: Universitetsforlaget.

Gamble, Andrew (1985): Britain in Decline. Economic Policy, Political Strategy and the British State, 2. ed. Houndsmill: Macmillan.

Halkier, Henrik (1987): Stalin eller kaos - Evolution og historie i kritisk samfundsteori, i: GRUS 22/23, 1987, 88-113.

Halkier, Henrik (1989): Difficult to Cure: The Decline of Britain and Industrial Policies. Århus: HHÅ.

Hall, Peter A. (1987): The State and Economic Decline. I: B. Elbaum \& W. Lazonick: The Decline of the British Economy. Oxford: Oxford UP, 266-302

Hirsch, Joachim \& Roland Roth (1986): Das neue Gesicht des Kapitalismus. Vom Fordismus zum Postfordismus. Hamburg.

Hood, Neil \& Stephen Young (eds.) (1984): Industry, Policy and the Scottish Economy. Edinburgh: Edinburgh UP.

Jensen, Carsten (1988): Om diskurs, snak og anden materiel eksistens, i: GRUS 24, 1988, 85-91.

Jessop, Bob (1983): Accumulation Strategies, State Forms, and Hegemonic Projects, i: Kapitalistate 10/11, 1983, 89-112.

Jessop, Bob et. al. (1988): Thatcherism. A Tale of Two Nations. Cambridge: Polity.

Keating, M. \& A. Midwinter (1983): The Government of Scotland. Edinburgh: Mainstream.

Laclau, Ernesto \& Chantal Mouffe (1985): Hegemony and Socialist Strategy. London: Verso.

Laclau, Ernesto \& Chantal Mouffe (1987): Post-marxism Without Apologies, i: New Left Review 166, 1987, 79-106.

McLennan, Gregor (1981): Marxism and the Methodologies of History. London: Verso.

McLennan, Gregor (1982): Philosophy and History: Some Issues in Recent Marxist Theory, i CCCS (eds.): Making Histories. Studies in History-writing and Politics. London: Hutchinson, 133-52.

McLennan, Gregor (1983): Historical Materialism Today: Some Variations and Problems, i Betty Matthews (ed.): Marx 100 Years On. London: Lawrence \& Wishart, 135-60.

Moore, C. \& S. Booth (1989): Managing Competition. Meso-Corporatism, Pluralism, and the Negociated Order in Scotland. Oxford: Clarendon. 
Pollard, Sidney (1983): The Development of the British Economy 1914-1980. London: Arnold.

Sayer, Andrew (1984): Method in Social Science. A Realist Approach. London: Hutchinson.

Scottish Development Agency (1981): Electronics in Scotland: The Leading Edge. Glasgow: SDA.

Scottish Development Agency (1985): Electronics, the State of the Art in Scotland. Glasgow: SDA.

Scottish Development Agency (1986a): Health Care in Scotland. The Front Runner. Glasgow: SDA.

Scottish Development Agency (1986b): Scotland - An Open Country. Glasgow: SDA.

Scottish Information Office: The Economy of Scotland. Edinburgh: SIO.

Warwick, P. (1985): Did Britain Change? An Inquiry Into the Causes of National Decline, i: Journal of Contemporary History 20, 1985, 99-133.

Wiener, Martin J. (1981): English Culture and the Decline of the Industrial Spirit, 19501980. Cambridge: Cambridge UP. 